\title{
4
}

\section{Viral Infections in ICU Patients}

\author{
David E. Greenberg ${ }^{1}$ and Stephen B. Greenberg ${ }^{2,3}$
}

NIAID $^{l}$, Laboratory of Clinical Infectious Diseases, Bethesda, Maryland 20892

Department of Medicine ${ }^{2}$ and Department of Molecular Virology and Microbiology ${ }^{3}$

Baylor College of Medicine, Houston, Texas 77030

\section{INTRODUCTION}

Intensive care units (ICU) were used originally for mechanical ventilation of patients with poliomyelitis and for recovery of patients after anesthesia. Today, these units have been expanded to care for severely ill patients with a wide variety of clinical conditions requiring close monitoring and support. A variety of medical conditions and physiologic disturbances have benefited from this care. Many critically ill patients have underlying infections and of those with infections, viruses are the cause in a small but important percentage $(1,2)$. The majority of viral infections which require care in an intensive care unit involve the respiratory or the central nervous system. However, other organ systems, such as the gastrointestinal tract, may be severely affected by viruses and require support or close monitoring. The conditions reviewed in this chapter are found in adults and do not include HIV infections. Table 1 is a summary of acute illnesses which may be caused by viruses and require treatment in an ICU in the Western Hemisphere. The syndromes and special hosts that are associated with severe viral infections may be diagnosed from epidemiologic clues and specific laboratory tests $(3,4)$. Clinical signs and symptoms are rarely sufficient to make a specific diagnosis of a viral infection.

\section{ACUTE RESPIRATORY FAILURE}

\subsection{Hypoxic $\rightarrow$ Viral Pneumonia}

Although severe community-acquired pneumonia is usually caused by bacteria, viruses account for approximately $3-10 \%$ of cases in large series $(5,6,7,8)$. The usual viral causes of pneumonia in adults are influenzavirus type A and B, parainfluenzaviruses, respiratory syncytial virus (RSV), and 
adenoviruses $(9,10,11)$. These pneumonias may be nosocomially acquired, especially during peak respiratory periods $(12,13,14,15,16)$.

Viruses can cause an atypical pneumonia in otherwise healthy individuals or a pneumonia in immunocompromised hosts $(17,18,19,20)$. The most common cause of viral pneumonia in adults is influenzavirus type A and B. Immunocompromised patients are more likely to have viral pneumonias caused by RSV, cytomegalovirus (CMV), herpes simplex virus (HSV), varicella-zoster virus (VZV), adenovirus and rarely measles (21-35). Radiographic findings are variable and not virus specific. Computed tomographic findings are also variable and overlap by virus etiology. Viral pneumonia may have poorly defined nodules and patchy areas of peribronchial ground-glass opacity and air-space consolidation. Hyperinflation is common (36).

Influenzavirus pneumonia is more likely to occur in the elderly and immunocompromised patient. Predisposing conditions for influenza pneumonia include age $>65$ years, diabetes mellitus, chronic lung disease, pregnancy, and immunosuppression. Influenzavirus pneumonia can be overwhelming and rapidly fatal (37-39). Influenzavirus infection can lead to bacterial superinfection and pneumonia secondary to Streptococcus pneumoniae and less commonly, Staphylococcus aureus. Diagnosis can be made by obtaining respiratory secretions and testing for viral antigen or virus growth in cell culture, or by serologic tests such as HI or ELISA. 


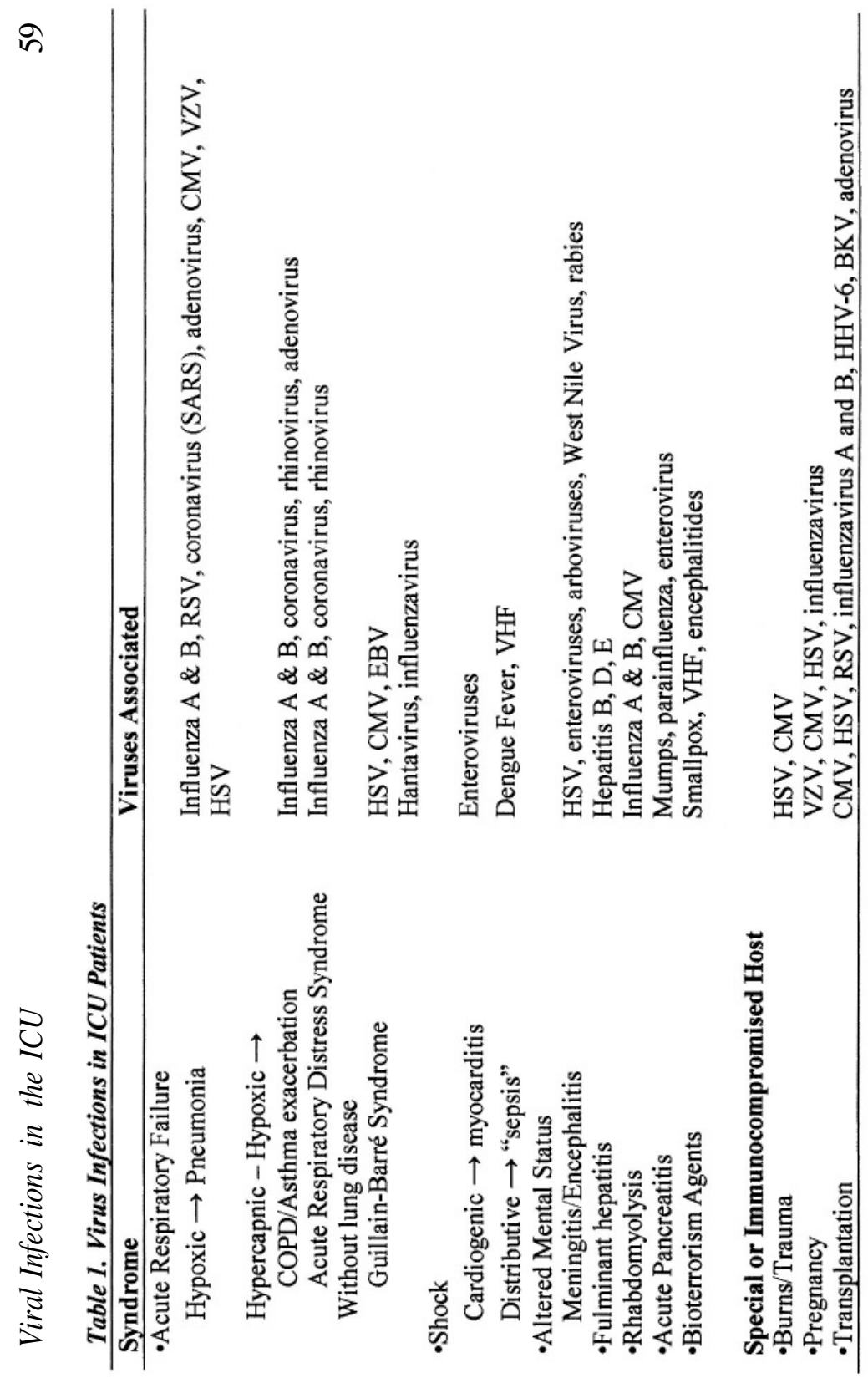


Although there are several antiviral agents which are effective against influenzavirus, there are few controlled studies on treatment of influenzavirus pneumonia. The older drugs, amantadine and rimantadine are useful against influenzavirus type A only and are only available in oral formulation. The newer neuraminidase inhibitors, oseltamivir and zanamivir are effective against influenzavirus types A and B, and are also only available in oral form $(40,41)$. Ribavirin can be given intravenously and has been shown to be effective in a few published cases of influenzavirus as well as RSV pneumonia (42-44).

Recent outbreaks of severe acute respiratory syndrome (SARS) have been published which have been associated with a new coronavirus (45). A case fatality rate of $4 \%$ to $15 \%$ has been reported in series from China and Canada (46). SARS should be considered in patients with the following history: travel in the previous 10 days to places with documented or a suspected SARS case; or close contact with a person with known or suspected SARS. Clinical illness includes cough, shortness of breath, hypoxia, and radiographic evidence of pneumonia or ARDS without another cause (47-50). Because SARS has been shown to transmit to healthcare personnel, isolation of patients is required. Standard, contact, and airborne isolation precautions should be initiated in suspected cases. All cases require notification to the local public health department and the Centers for Disease Control.

\subsection{Hypercapnic-Hypoxic}

2.2.1 COPD/Asthma Exacerbation. Acute respiratory failure can occur in patients with chronic obstructive pulmonary disease (COPD) and lead to hospitalization and the need for mechanical ventilation (51). Patients with exacerbations of COPD often have a history of increased sputum production, dyspnea and cough. Documented viral infections occurs in up to $45 \%$ of episodes of exacerbation of COPD $(52,53)$. The most frequently identified viruses in acutely ill COPD patients are rhinoviruses, parainfluenzaviruses, coronaviruses, and influenzaviruses type A and $\mathrm{B}$ (53). In severely ill adult patients requiring hospitalization and mechanical ventilation, influenzaviruses and coronaviruses are most common. The epidemiology of acute exacerbations in adult asthmatic patients is similar. With acute, severe, exacerbations of asthma, patients may require close monitoring and ventilatory support. Recent studies have confirmed the importance of rhinoviruses, parainfluenzaviruses, and influenzaviruses in over half the acute exacerbations in adult asthmatics (54). 
2.2.2 Acute Respiratory Distress Syndrome (ARDS). ARDS is characterized by severe hypoxemia and diffuse infiltrates on chest x-ray in the absence of clinical heart failure. ARDS has many causes. Common illnesses associated with ARDS include sepsis, diffuse pneumonia, aspiration or severe trauma. Although bacteria are more often the cause of infections leading to ARDS, viruses have been identified, especially influenzavirus, Hantavirus, varicella, herpes simplex virus and SARS (5557).

Hantaviruses cause very different illnesses in Europe and Asia as opposed to the Americas $(58,59)$. Epidemics of hemorrhagic fever with renal syndrome (HFRS) are caused by Hantaan, Dobravna, and Seoul viruses. Hantavirus pulmonary syndrome (HPS) is spread by New World rats and mice carrying one of the dozen reported viruses of the Bunyavirus family. Sin Nombre virus is the major pathogen causing HPS in the United States (60). HPS causes a non-cardiogenic pulmonary edema after initial influenza-like symptoms. HPS has a higher mortality than HFRS. The virus is transmitted to humans by inhalation of aerosolized particles of rodent excreta or by direct rodent contact. HPS has been recognized in 31 states, most commonly in the western region of the United States. Laboratory abnormalities include thrombocytopenia, leukocytosis, hemoconcentration, and the presence of immunoblasts on peripheral smear (61,62). Diagnosis requires serologic detection of $\operatorname{IgM}$ and $\operatorname{IgG}$ antibodies to Sin Nombre virus. Mortality rates may approach $40 \%$. Although there is no specific therapy, cardiopulmonary support in an ICU may be associated with improved survival.

\subsection{Without Lung Disease.}

Guillain-Barré Syndrome (GBS) is the most common cause of acute neurogenic respiratory failure. Ventilatory assistance will be necessary in up to one-third of patients with this acute inflammatory disseminated polyneuropathy (AIDP). If respiratory failure occurs, it usually does so during the first two weeks of the illness. An antecedent respiratory or gastrointestinal illness is commonly reported in the preceding four weeks prior to the onset of symptoms $(63,64,65)$. Viruses commonly reported in GBS patients include influenzavirus, CMV, acute and chronic hepatitis B, EBV, and varicella-zoster virus (66-75). Rare cases have been reported and associated with West Nile virus, Parvovirus B19, Hantavirus, rubella, and dengue (76-80).

The care of these patients in ICUs has significantly reduced mortality rates. In patients requiring mechanical ventilation, plasma exchange has 
shortened the duration of respiratory support (81). An alternative treatment to plasma exchange appears to be IVIg. Even with treatment, the rehabilitation process is long and residual weakness is found in approximately $15 \%$.

\section{SHOCK}

\subsection{Cardiogenic $\rightarrow$ Myocarditis}

Cardiogenic shock may develop following acute myocardial infarction or severe heart failure from any cause. Clinically, Cardiogenic shock is manifested by peripheral hypoperfusion, cold extremities, cyanosis, or hypotension. Viral infection of the myocardium can lead to clinical myocarditis which is severe enough to manifest Cardiogenic shock either due to myocardial failure or tachyarrhythmias $(82,83)$.

Although rarely proven, viruses are suspected as the major causes of acute myocarditis. A suspicion of viral myocarditis should be high in patients who had fever and myalgias preceding the development of cardiac symptoms. Evidence of myocardial damage with elevated creatine kinase and troponin levels is common. Patients may present with typical anginal chest pain and/or arrhythmias; making it difficult to rule out an acute myocardial infarction (84).

The viruses documented in myocarditis cases are predominantly enteroviruses, especially coxsackie B viruses (85). However, influenzavirus, adenoviruses, Parvovirus B19, and CMV have been reported, as well (86-92). Recent smallpox vaccine studies have also reminded us of the potential for myocarditis with vaccinia virus. Most patients with acute myocarditis have mild heart failure, but occasionally, the myocarditis and associated organ dysfunction is severe enough to require mechanical ventricular assist devices until resolution or cardiac transplantation is available.

\subsection{Distributive "Sepsis"}

3.2.1 Dengue Fever. Dengue hemorrhagic fever (DHF), and dengue shock syndrome (DSS) have become increasingly prevalent in the past decade (93-95). The principal vector, Aedes aegypti, as well as Aedes albopictus, or the tiger mosquito, was brought to Houston, Texas from Japan in the 1980's. Clinically, dengue fever presents with high fever, severe headaches, myalgias, joint pains, maculopapular rash and leukopenia. Petechiae secondary to thrombocytopenia can be observed. 
DHF/DSS are severe forms of the infection. The main pathophysiologic changes seen in DHF/DSS patients are abnormal hemostasis and plasma leakage.

With DHF/DSS, patients present with high fever, facial flushing and headache. Hemorrhagic manifestations such as bleeding at venipuncture sites, petechiae, epistaxis, gingival bleeding, and gastrointestinal hemorrhage may be observed. The tourniquet test is often positive. After the patient becomes afebrile, profuse sweating and a drop in blood pressure are observed. Once shock develops, the patient's condition deteriorates and death may occur without support. Recent series have reported DSS in the absence of thrombocytopenia and hemoconcentration. Mortality rates vary from 2-10\% for DHF.

Risk factors for DHF/DSS in the Americas include 1) secondary infection with a different serotype; 2) sequential serotypes in secondary infections; 3 ) association with dengue 2 virus and, less frequently, dengue 3 virus; 4) longer interval between first and second infection; 5) young age; 6) lower frequency in blacks; and 7) individuals with a history of asthma, diabetes mellitus, or sickle cell anemia (93). To consider a case, the travel history and local disease occurrence must be known. Diagnosis is made by detection of $\operatorname{IgM}$ antibody. Paired sera for the testing of specific rises in IgG antibody will give a more specific diagnosis. Treatment for DHF/DSS is supportive.

3.2.2 Viral Hemorrhagic Fevers (VHF). Viral hemorrhagic fevers (VHF) are caused by RNA viruses and transmitted by rodent or arthropod vectors. In the case of Marburg and Ebola viruses, the reservoir and mode of transmission remain unknown. Case-fatality rates vary from $1 \%$ to 90\%. Clinical syndromes include hemorrhage secondary to capillary leakage, hepatitis, encephalitis, and/or nephropathy. Disseminated intravascular coagulopathy (DIC) is common to many but not all of these viruses. The viruses found naturally in the Western hemisphere include yellow fever, dengue, Sin Nombre virus (Hantavirus), and South American hemorrhagic fever viruses (Guanarito, Sabia, Junin, and Machupo) (Table 2). Other viruses indigenous to Africa and Asia include Rift Valley fever, Crimean-congo hemorrhagic fever, Kyasanur Forest virus, Omsk hemorrhagic fever, hemorrhagic fever with renal syndrome, Lassa fever, and African hemorrhagic fever (Marburg and Ebola). The hemorrhagic fever viruses in Asia and Africa have the potential for introduction into the Western hemisphere or for use as biological warfare agents. 
Table 2. Viral Hemorrhagic Fevers (VHF) in the Western Hemisphere

\begin{tabular}{|c|c|c|c|}
\hline & Flaviviridae & Bunyaviridae & Arenaviridae \\
\hline Disease & $\begin{array}{l}\text { Yellow fever } \\
\text { Dengue HF }\end{array}$ & $\begin{array}{l}\text { Hantavirus } \\
\text { Pulmonary } \\
\text { Syndrome }\end{array}$ & $\begin{array}{l}\text { Venezuelan, } \\
\text { Brazilian, } \\
\text { Argentine, \& } \\
\text { Bolivian HF }\end{array}$ \\
\hline Clinical Syndromes & $\begin{array}{l}\text { Hemorrhage, } \\
\text { hepatitis, } \\
\text { nephropathy }\end{array}$ & $\begin{array}{l}\text { ARDS, hepatitis, } \\
\text { nephropathy }\end{array}$ & $\begin{array}{l}\text { Hemorrhage, } \\
\text { encephalitis, } \\
\text { nephropathy }\end{array}$ \\
\hline Case-fatality Rate & $2-20 \%$ & $40-50 \%$ & $10-33 \%$ \\
\hline Treatment & $\begin{array}{l}\text { Supportive care, } \\
\text { close monitoring, no } \\
\text { aspirin, no steroids, } \\
\text { fluid resuscitation }\end{array}$ & $\begin{array}{l}\text { Oxygenation and } \\
\text { monitoring } \\
\text { crystalloid fluid } \\
\text { replacement, } \\
\text { ribavirin IV } \\
\text { (experimental) }\end{array}$ & $\begin{array}{l}\text { Supportive therapy, } \\
\text { specific immune } \\
\text { human plasma } \\
\text { (Argentine HF) }\end{array}$ \\
\hline
\end{tabular}

The viruses causing hemorrhagic fever cause microvascular damage and alterations in vascular permeability $(96,97)$. Fever, prostration, and myalgias are common initial symptoms. Physical examination will often reveal hypotension, facial flushing, and petechiae. With progression to shock and generalized bleeding, there is often hematopoietic, neurologic and pulmonary involvement. Hepatitis is common and severe with yellow fever but not with the other VHF agents of the Western hemisphere. Increasing vascular permeability, loss of intravascular volume, and multiorgan failure are often the final pathway to death.

Routine laboratory tests yield nonspecific abnormalities, but thrombocytopenia and coagulation defects should suggest the diagnosis with the corresponding clinical presentation. Specific diagnosis requires isolation of the virus or staining of formalin-fixed tissue. Only the CDC and USAMRIID laboratories are under Biolevel safety 4 conditions which are necessary for attempting isolation of these viruses. RT-PCR assays for rapid diagnosis may become more widely available in the future.

The care of patients with VHF is largely supportive. Patients in shock and actively bleeding will require close monitoring, fluid resuscitation as well as transfusion of red cells, platelets, and clotting factors $(98,99)$. No aspirin or corticosteroids should be used. Dopamine may be the pressor of choice in unresponsive shock. Only ribavirin has been used successfully in VHF, especially for Lassa fever patients. Experimental use of ribavirin in Hantavirus pulmonary syndrome is being evaluated. Specific immune human plasma has been successful in treating Argentine hemorrhagic fever and may be useful in Bolivian hemorrhagic fever. 
All suspected VHF cases should be placed in isolation immediately. Respiratory precautions and placement in a negative pressure room should help reduce the spread to hospital personnel and close contacts. All specimens must be appropriately labeled. Decontamination of all areas where the patient has been is essential. Reporting all suspected cases to local, state, and federal authorities is necessary to alert the community of a possible outbreak.

\section{ALTERED MENTAL STATUS}

\subsection{Viral Meningitis and Encephalitis}

The differential diagnosis of viral meningitis and encephalitis includes a long list of viruses as well as bacteria and noninfectious conditions. Because the clinical presentation of viral meningitis and encephalitis overlaps with other infections and illnesses, the diagnostic evaluation and therapeutic management are complicated. The most common viral pathogens associated with meningitis or encephalitis and their epidemiology are listed in Table 3 (100-103).

Viral meningitis and encephalitis cases occur worldwide. In the United States, echoviruses and coxsackie viruses (non-polio enteroviruses) are the cause of many cases of meningitis and some cases of encephalitis. (104). Although outbreaks are more common in the summer months, CNS enteroviral illness occurs throughout the year. The most common cause of sporadic cases of encephalitis in adults is HSV-1. Over 50\% of the cases of encephalitis in adults older than 50 years are caused by HSV-1 (105). Outbreaks of encephalitis can be caused by alphaviruses and/or flaviviruses such as St. Louis Encephalitis. West Nile virus infection and illness has only been reported in the United States since 1999 (106). However, severe CNS infections and deaths from West Nile virus are being reported with increased frequency throughout many states during 2002 and 2003 (107). Rare cases of rabies are reported annually in the United States, but the mortality rate in these patients approaches $100 \%$ $(108,109)$.

The clinical presentation of viral meningitis and encephalitis often includes fever, headache, vomiting, altered mental status, and seizures. On neurologic examination, hyperreflexia, cognitive alterations, ataxia, and focal findings are common. Examination of the cerebrospinal fluid is necessary for evaluating these patients and sending specimens for diagnosis. Typically, patients with viral meningitis and encephalitis have elevated protein levels, normal glucose levels and a lymphocytosis. In 
some cases, there may be a neutrophil pleocytosis and/or mild hypoglycorrhachia. These findings will often prompt clinicians to begin broad-spectrum antibiotics as well as antivirals until culture and PCR results are known. Magnetic resonance imaging (MRI) can demonstrate a pattern that suggests a specific pathogen such as HSV-1 or Japanese encephalitis. In other cases, the MRI may be normal. In herpes simplex encephalitis (HSE), 95\% of patients have a history of change in the level of consciousness, $90 \%$ have fever, $85 \%$ have personality change, and $80 \%$ have headaches. Seizures have been reported in approximately two-thirds of patients. Other signs and symptoms include aphasia, amnesia and/or hallucinations. Typically, the CSF profile includes elevated opening pressure, lymphocytes, red blood cells and slightly elevated protein level. After 18 to 24 hours of symptoms, approximately $95 \%$ of CSF samples will have a positive PCR test (110). Serum antibody assays are not helpful in diagnosis. EEG shows lateralized epileptiform discharges (PLEDs) over the temporal or frontal area in $85 \%$ of patients with HSE. In the first 5 to 6 days of illness, the CT scan maybe normal. MRI is more likely to be abnormal earlier than the CT scan. Brain biopsy, although the definitive diagnostic procedure, is only performed when there is an atypical clinical, radiologic, or laboratory picture. The mortality rate has been reduced to $20 \%$ with acyclovir therapy. However, the mortality rate is higher in those older than 30 years and in those who were comatose before treatment was initiated.

West Nile virus had been a cause of encephalitis in Africa and the Middle East until 1999, when it was found in fatal cases of encephalitis in New York City $(111,112)$. Over the next few years, hundreds of cases had been confirmed throughout most of the United States. West Nile virus is a member of the Flaviviridae family. Most infected patients are asymptomatic. Clinical illness is associated with fever, headache, anorexia and malaise. Lymphadenopathy has been reported in earlier epidemics. A maculopapular rash over the chest, back, and upper extremities is observed in approximately $50 \%$ of cases. Other signs and symptoms include conjunctivitis, nausea, abdominal pain, and diarrhea $(113,114)$.

Meningitis, encephalitis, and acute flaccid paralysis have been reported with West Nile virus (115-117). CSF examination usually reveals a lymphocytic pleocytosis and elevated protein level. Guillain-Barré syndrome has also been reported. Diagnosis can be made by serologic tests, but cross-reactive antibodies to other flaviviruses have been observed. Detection of virus by RT-PCR is positive in less than $50 \%$ of cases. 
Patients may need prolonged ventilation because of neurologic complications. No specific therapy has been found to be effective, although interferon, ribavirin and IVIg have been tested or proposed for clinical trials. Recovery may be prolonged with neurologic abnormalities being reported for up to one year following the illness.

Specimens should be collected for viral isolation and PCR testing. CSF PCR tests are available for detecting HSV-1, CMV, EBV, VZV, HHV-6, HHV-7, and the enteroviruses. In HSV-1 encephalitis, the sensitivity of CSF PCR approaches 95\% (118). Less information is available on the sensitivity of CSF PCR tests for the other viruses.

For many patients with meningitis, admission to the hospital will not be necessary. Patients with suspected encephalitis should be admitted to the hospital and monitored closely. Initiation of empiric acyclovir intravenously should be considered. An MRI should then be reviewed for evidence of mass effect. If significant mass effect is present, then the CSF examination should be deferred and evidence of increased intracranial pressure (ICP) would require specific treatment (119). If no mass effect is found, then CSF examination should be performed and the appropriate tests ordered. If the HSV PCR test is negative, consider other diagnoses unless MRI is compatible with HSV.

Table 3. Epidemiology of Viral Encephalitis/Meningitis in the Western Hemisphere

\begin{tabular}{lll}
\hline Virus & Clinical Findings & Epidemiology \\
\hline Enteroviruses & Myocarditis, rash pleurodynia & $\begin{array}{l}\text { Summer and fall peaks both } \\
\text { epidemic; sporadic cases }\end{array}$ \\
$\begin{array}{l}\text { Herpes Simplex Type 1 } \\
\text { Herpes Simplex Type 2 } \\
\text { Varicella-Zoster virus }\end{array}$ & $\begin{array}{l}\text { Focal neurologic deficits } \\
\text { Primary genital lesions }\end{array}$ & $\begin{array}{l}\text { No seasonality; sporadic } \\
\text { No seasonality; sporadic }\end{array}$ \\
EBV/CMV & $\begin{array}{l}\text { Mononucleosis syndrome, } \\
\text { immunosuppressed }\end{array}$ & $\begin{array}{l}\text { No seasonality; sporadic } \\
\text { No seasonality; sporadic }\end{array}$ \\
HHV-6 & Focal neurologic & No seasonality; sporadic \\
EEE/WEE/VEE & Mosquito-borne, seizures & Summer; epidemic \\
SLE/WNV & Mosquito-borne, SIADH, & No seasonality; sporadic \\
California & acute flaccid paralysis & Northern Central US; \\
Influenzavirus & Seizures & summer; epidemic \\
LCM & Pneumonia & Winter; epidemic \\
& --- & $\begin{array}{l}\text { Contact with rodents; } \\
\text { winter; sporadic }\end{array}$ \\
Mumps & & Spring/summer; sporadic \\
Rabies & Parotitis & History of animal bite; no \\
& Hydrophobia & seasonality; sporadic \\
\hline
\end{tabular}




\section{FULMINANT HEPATITIS}

In $1 \%$ to $2 \%$ of patients with acute hepatitis, acute liver failure or fulminant hepatitis will occur (120). Patients with fulminant hepatitis will often manifest encephalopathic changes, jaundice, and a prolonged prothrombin time. Levels of elevated aminotransferases do not have prognostic value and may decrease as the liver failure becomes worse. The viruses reported in cases of fulminant hepatitis are hepatitis B and D, $\mathrm{A}$ and $\mathrm{E}$ and rarely $\mathrm{C}(121,122)$. A recent study reports that approximately $12 \%$ of acute liver failure causes are attributable to viral hepatitis (123). Occasional cases of herpes simplex and varicella hepatitis have been reported in immunocompetent and immunosuppressed adults (124-126). A recent study has found HHV-6 antigens in explanted livers of patients with acute liver failure of unknown etiology (127).

\section{RHABDOMYOLYSIS}

Rhabdomyolysis is a syndrome characterized by muscle weakness, pain and cramps. Complications may be extramuscular and lead to acute renal failure and severe metabolic abnormalities $(128,129)$. Rhabdomyolysis may be purely related to exertion, genetically determined or due to nonhereditary, nonexertional causes. Viruses have been reported to be rare precipitative causes of rhabdomyolysis $(130,131)$. These viruses have been cytomegalovirus, measles, adenovirus, varicella, EBV, influenzavirus, parainfluenzavirus and enteroviruses (132-150).

\section{PANCREATITIS}

Acute pancreatitis is characterized by abdominal pain and elevated serum amylase and lipase (151). Depending upon the severity of the pancreatitis, the patient may need mechanical ventilation and support in an intensive care unit. The majority of cases are caused by gallstones and alcohol. Pancreatitic obstruction, drugs and toxins, metabolic and genetic disorders, trauma and iatrogenic causes account for most of the remaining cases. Several viruses are rare causes of acute pancreatitis: mumps, coxsackievirus, cytomegalovirus, hepatitis $\mathrm{B}$, varicella-zoster virus, herpes simplex virus, hepatitis $\mathrm{C}$, enterovirus 71 , hepatitis $\mathrm{E}$, hepatitis $\mathrm{A}$, and adenovirus (152-160). 


\section{BIOTERRORISM AGENTS}

The possible use of biological agents in a terrorist attack has become quite real since September 11, 2001 and the subsequent distribution of anthrax $(161,162)$. Potential biological weapons have included both bacteria and viruses. The chief viral candidates with the greatest impact are smallpox, viral hemorrhagic fever agents such as Ebola virus, and equine encephalitis $(163,164)$. Delivery of the virus weapon is likely to be by the respiratory route; contamination of food or water is less likely.

\subsection{Smallpox}

A single case of smallpox would have significant impact on the health care system (165). Smallpox is caused by variola virus and is highly infectious. Spread may occur by person-to-person or by fomites. After a 12 to 14 day incubation period, a prodromal illness marked by fever, rigors, malaise, headache and backache will last approximately three days. During this time, the physician examining the patient will consider a "flulike" illness is most likely (166). A discrete centrifugal rash characterized by macules begins on the face, hands, and forearms (167). The macules become papules and then vesicles which spread over the whole body. Pustules and crusted lesions develop by the eighth day and thirteenth day, respectively. The rash can be distinguished from varicella (chickenpox) by being more peripheral and progressing at the same stage over the skin.

Mortality may reach $30 \%$ and is highest during the second week of illness. Pulmonary edema and hemoptysis were commonly reported in earlier outbreaks. Renal failure and electrolyte abnormalities also contributed to the morbidity in smallpox patients.

If a suspected case of smallpox were admitted to the hospital or ICU, the physician would need to notify local and national public health officials. Specimens should be sent for diagnosis to state and national laboratories where biosafety level 4 precautions are available.

A suspected case of smallpox needs to be placed in strict airborne and contact isolation and in a negative-pressure room. Patient transport should be limited. Dedicated equipment should be used. Linens from the patient should be autoclaved before laundering (Table 4). Isolation of the patient should be continued until all scabs separate.

Smallpox patients will need monitoring and excellent skin care. There is no currently approved antiviral treatment, although cidofovir has been 
shown to be effective in vitro and in animal models $(168,169)$. Vaccination of contacts should limit the development of clinical disease if administered within four days of exposure (170).

\subsection{Viral Hemorrhagic Fevers (VHF)}

VHF are caused by a diverse group of viruses that are transmitted by animal and arthropod vectors (171). VHF agents are potential biologic weapons because they are highly infectious, stable as aerosols, and cause high morbidity and mortality. These viral agents can infect by direct contact with needles, fluids and tissues of other infected patients, however aerosol infection in humans has not been reported with the exception of Hantavirus.

All suspected cases of VHF should be placed in isolation in negativepressure rooms. Airborne, droplet and contact precautions should be instituted. Patient transport should be limited and masks should be placed if transport is essential. Dedicated equipment should be left in the patient's room. Disinfection of surfaces with $10 \%$ bleach solution or phenolic disinfectant is recommended. The patient should remain in isolation for the duration of the illness (Table 4). 
Table 4. Isolation Guidelines for Presumed or Documented Viral Infections Related to Bioterrorism*

\begin{tabular}{|c|c|c|c|c|}
\hline & \multicolumn{4}{|c|}{ Virus } \\
\hline & Smallpox & VEE $^{*}$ & $\begin{array}{l}\text { Viral } \\
\text { Enceph. }\end{array}$ & VHF \\
\hline \multicolumn{5}{|l|}{ Isolation Precautions } \\
\hline Standard Precautions & $\mathrm{X}$ & $\mathrm{X}$ & $\mathrm{X}$ & $\mathrm{X}$ \\
\hline Contact Precautions (gowns and gloves) & $\mathrm{X}$ & & & $\mathrm{X}$ \\
\hline $\begin{array}{l}\text { Airborne Precautions (negative pressure room } \\
\& \text { N95 masks for all individuals entering } \mathrm{rm} \text { ) }\end{array}$ & $\mathrm{X}$ & & & \\
\hline Droplet Precautions (surgical mask) & & & $\mathrm{X}$ & \\
\hline \multicolumn{5}{|l|}{ Patient Placement } \\
\hline \multicolumn{5}{|l|}{ No restrictions } \\
\hline $\begin{array}{l}\text { Cohort "like" patients when private room } \\
\text { unavailable }\end{array}$ & $\mathrm{X}$ & & $\mathrm{X}$ & \\
\hline Private Room & $\mathrm{X}$ & $\mathrm{X}$ & & $\mathrm{X}$ \\
\hline Negative Pressure & $\mathrm{X}$ & & & \\
\hline Door closed at all times & $\mathrm{X}$ & & & \\
\hline \multicolumn{5}{|l|}{ Patient Transport } \\
\hline No restrictions & & & $\mathrm{X}$ & \\
\hline $\begin{array}{l}\text { Limit movement to essential medical purposes } \\
\text { only }\end{array}$ & $\mathrm{X}$ & $\mathrm{X}$ & & $\mathrm{X}$ \\
\hline $\begin{array}{l}\text { Place mask on patient to minimize dispersal of } \\
\text { droplets }\end{array}$ & & $\mathrm{X}$ & & \\
\hline \multicolumn{5}{|l|}{ Cleaning, Disinfection of Equipment } \\
\hline $\begin{array}{l}\text { Routine terminal cleaning of room with } \\
\text { hospital approv. Disinfectant upon discharge }\end{array}$ & $\mathrm{X}$ & $\mathrm{X}$ & $\mathrm{X}$ & \\
\hline $\begin{array}{l}\text { Disinfect surfaces with bleach/water sol. 1:9 } \\
\text { (10\% sol.) }\end{array}$ & & & & $\mathrm{X}$ \\
\hline $\begin{array}{l}\text { Dedicated equipment (disinfect prior to } \\
\text { leaving room) }\end{array}$ & $\mathrm{X}$ & & & $\mathrm{X}$ \\
\hline Linen management as with all other patients & $\mathrm{X}$ & $\mathrm{X}$ & $\mathrm{X}$ & $\mathrm{X}$ \\
\hline \multicolumn{5}{|l|}{ Post-mortem Care } \\
\hline Follow principles of Standard Precautions & $\mathrm{X}$ & $\mathrm{X}$ & $\mathrm{X}$ & $\mathrm{X}$ \\
\hline \multicolumn{5}{|l|}{ Droplet Precautions } \\
\hline $\begin{array}{l}\text { Airborne Precautions (negative pressure room } \\
\& \text { N95 masks for all individuals entering } \mathrm{rm} \text { ) }\end{array}$ & $\mathrm{X}$ & & & \\
\hline
\end{tabular}

Adapted from Karwa M, et al. Bioterrorism and Critical Care. Crit Care Clin 2003; 19:279-313, with permission)

*VEE $=$ Venezuelan Equine Encephalitis

\section{SPECIAL OR IMMUNOSUPPRESSED HOSTS}

\subsection{Burns/Trauma}

Burn patients have been reported to have a high incidence of herpes simplex virus (HSV) infections manifested as ARDS and occasionally as pneumonia (172-174). Necrotizing tracheobronchitis, and facial rashes 
have also been found in these patients (175-179). With acyclovir therapy, there has been reported clinical improvement. Isolation of HSV from bronchoalveolar lavage specimens is associated with the need for assisted ventilation in burn patients $(180,181)$. However, there are conflicting studies on whether HSV activation is associated with increased mortality in these patients (182). A recent prospective study culturing for HSV in the respiratory tract of patients in critical care units showed HSV reactivation was frequent and associated with ARDS and increased length of stay in intensive care (183). This confirmed results from other older studies $(184,185)$. Similar findings have also been found in critically ill surgical patients (186-188).

\subsection{Pregnancy}

There are numerous physiologic and immunologic changes in pregnancy that create a state of relative immunosuppression (189). Pregnant women are more susceptible to a variety of viral infections including pneumonia $(189,190)$. Influenzavirus, VZV, and measles have all been reported as causes of pneumonia (191-194). Complications of VZV can be particularly devastating during pregnancy. Ninety percent of adults living in nontropical areas are immune to varicella, therefore most pregnant women are not susceptible (195). Pneumonia can occur a few days after the development of rash and fever and can lead to respiratory failure. Both the mother and fetus can suffer morbidity and mortality from varicella. Patients with the complication of varicella pneumonia should be treated aggressively with antiviral therapy and close monitoring (194-197). Acyclovir is generally accepted as the treatment of choice despite the lack of safety studies (198). In pregnant women with no history of VZV who have an exposure, the use of VZIG may be beneficial in preventing maternal infection (199). Another virus that may lead to admission to the ICU is HSV. HSV infection can affect both the mother and the developing fetus (200-202). HSV of the genital tract can be transferred to the newborn and result in severe and life-threatening disease (203). Although rare, HSV type 2 causing encephalitis following cesarean section has been reported (204). Finally, given recent concerns regarding bioterrorism, it is important to realize that smallpox has had high mortality in the pregnant woman compared to the non-pregnant woman (205).

\subsection{Transplantation}

Viral infections can cause severe morbidity and mortality in both solidorgan and stem cell transplant patients (206-211). These infections can manifest as either primary infection or reactivation of latent disease $(212,213)$. Viral infections in transplant patients may present as a variety 
of clinical syndromes that require ICU stays. These include pneumonia, encephalitis, hepatitis and gastroenteritis (180,214-219).

The variety of clinical presentations and radiographic features make diagnosis of specific viruses difficult. In the transplant patient, common community respiratory viruses such as influenzaviruses $\mathrm{A}$ and $\mathrm{B}$, respiratory syncytial virus (RSV), adenovirus and parainfluenzavirus (PIV) can lead to fulminant pneumonia, respiratory failure and death (4,220-224). There has been increased mortality reported in hematopoietic stem cell transplant patients who develop RSV or PIV infection (225227). Occasional cases with metapneumovirus have been reported in stem cell transplant recipients $(228,229)$. Both ribavirin with and without IVIG have been used to treat RSV pneumonia; but mortality remains high $(33,230,231)$.Treatment benefit is generally seen when used prior to the development of respiratory failure (232). Other respiratory viruses that can lead to severe pneumonia are rhinoviruses and adenoviruses (233). Solid organ transplant recipients also are at risk of developing severe lower respiratory tract viral infections. One study found a high incidence of influenza among lung transplant patients, but liver and kidney transplant patients also develop influenza (234).

The Herpesviruses cause a variety of clinical syndromes in transplant patients. CMV, EBV, VZV, HSV, HHV-6 and HHV-8 have all been reported to cause disease (188,235-238). CMV disease constitutes a serious problem in bone marrow transplant recipients with a 30-50\% incidence of clinically significant infections $(239,240)$. Pneumonitis is the most serious complication and was associated with high mortality prior to antiviral therapy (241). Ganciclovir and foscarnet have been frequently used for prophylaxis and treatment of CMV (242-245). Hyperimmune globulin in combination with antivirals has also been used for treatment of disease (246). Ganciclovir resistance in CMV has been reported and should be considered when clinical responses do not occur (247). EBV can reactivate in transplant recipients and lead to uncontrolled B-cell proliferation and post-transplant lymphoproliferative disorder (PTLD) (248). This can present as frank lymphoma with high mortality rates. Donor lymphocyte infusions and anti-CD20 antibody has been used for treatment (249). HSV can present as both severe mucocutaneous disease or in rare cases encephalitis (250). HSV disease results from reactivation of latent virus (251). Other viruses that cause encephalitis in transplant patients are CMV, VZV, EBV, HHV-6 and recently West Nile Virus (252). Cases of encephalitis usually require treatment in the ICU. In this patient population, viral pneumonia and encephalitis require care in an 
ICU setting. Although viral culture has been the gold standard for diagnosis, PCR has become the new diagnostic standard $(225,253)$.

\section{REFERENCES}

1. Chernoff AE, Snydman DR. Viral infections in the intensive care unit. New Horiz 1993;1:279-301.

2. Couch RB, Englund JA, Whimbey E. Respiratory viral infections in immunocompetent and immunocompromised persons. Am J Med 1997;102(3A):2-9.

3. Greenberg SB. Infections in the immunocompromised rheumatologic patient. Crit Care Clin 2002;18:931-56.

4. Hicks KL, Chemaly RF, Kontoyiannis DP. Common community respiratory viruses in patients with cancer: more than just "common colds". Cancer. 2003;97:2576-87.

5. Dowell SF, Anderson LJ, Gary HE Jr, Erdman DD, Plouffe JF, File TM Jr, Marston BJ, Breiman RF. Respiratory syncytial virus is an important cause of community-acquired lower respiratory infection among hospitalized adults. J Infect Dis 1996;174:456-62.

6. Dudding BA, Wagner SC, Zeller JA, Gmelich JT, French GR, Top FH Jr. Fatal pneumonia associated with adenovirus type 7 in three military trainees. N Engl J Med 1972;286:1289-92.

7. Greenberg SB. Viral pneumonia. Infect Dis Clin North Am 1991;5:603-21.

8. Rello J, Diaz E. Pneumonia in the intensive care unit. Crit Care Med 2003;31:2544-51.

9. Baine WB, Luby JP, Martin SM. Severe illness with influenza B. Am J Med 1980;68:181-9.

10. Luksza AR, Jones DK. Influenza B virus infection complicated by pneumonia, acute renal failure and disseminated intravascular coagulation. J Infect 1984;9:174-6.

11. Motallebi M, Mukunda BN, Ravakhah K. Adenoviral bronchopneumonia in an immunocompetent adult: computed tomography and pathologic correlations. Am J Med Sci 2003;325:285-7.

12. Aitken C, Jeffries DJ. Nosocomial spread of viral disease. Clin Microbiol Rev 2001;14:528-46.

13. Holladay RC, Campbell GD Jr. Nosocomial viral pneumonia in the intensive care unit. Clin Chest Med 1995;16:121-33.

14. Ibrahim EH, Ward S, Sherman G, Kollef MH. A comparative analysis of patients with early-onset vs late-onset nosocomial pneumonia in the ICU setting. Chest 2000;117:1434-42.

15. Raad I, Abbas J, Whimbey E. Infection control of nosocomial respiratory viral disease in the immunocompromised host. Am J Med 1997;102:48-52

16. Valenti WM. "Selected Viruses of Nosocomial Importance." In Hosptial Infections $4^{\text {th }}$ ed., JV Bennett and PS Brachman, ed. Philadelphia PA: LippincottRaven, 1998.

17. Whimbey E, Bodey GP. Viral pneumonia in the immunocompromised adult with neoplastic disease: the role of common community respiratory viruses. Semin Respir Infect. 1992;7:122-31.

18. Whimbey E, Champlin RE, Couch RB, Englund JA, Goodrich JM, Raad I, Przepiorka D, Lewis VA, Mirza N, Yousuf H, Tarrand JJ, Bodey GP. 
Community respiratory virus infections among hospitalized adult bone marrow transplant recipients. Clin Infect Dis 1996;22:778-82.

19. Whimbey E, Couch RB, Englund JA, Andreeff M, Goodrich JM, Raad II, Lewis V, Mirza N, Luna MA, Baxter B, et al. Respiratory syncytial virus pneumonia in hospitalized adult patients with leukemia. Clin Infect Dis 1995;21:376-9.

20. Whimbey E, Ghosh S. Respiratory syncytial virus infections in immunocompromised adults. Curr Clin Top Infect Dis 2000;20:232-55.

21. Arata K, Sakata R, Iguro Y, Toda R, Watanabe S, Eitsuru Y. Herpes simplex viral pneumonia after coronary artery bypass grafting. Jpn J Thorac Cardiovasc Surg 2003;51:158-9.

22. de la Hoz RE, Stephens G, Sherlock C. Diagnosis and treatment approaches of CMV infections in adult patients. J Clin Virol 2002;25 Suppl 2:S1-12.

23. Eisenstein LE, Cunha BA. Herpes simplex virus pneumonia presenting as failure to wean from a ventilator. Heart Lung 2003;32:65-6.

24. Feldman S, Stokes DC. Varicella zoster and herpes simplex virus pneumonias. Semin Respir Infect 1987;2:84-94.

25. Graham BS, Snell JD Jr. Herpes simplex virus infection of the adult lower respiratory tract. Medicine (Baltimore) 1983;62:384-93.

26. Greenberg SB. Respiratory herpesvirus infections. An overview. Chest 1994;106:1S-2S.

27. Guidry GG, Black-Payne CA, Payne DK, Jamison RM, George RB, Bocchini JA Jr. Respiratory syncytial virus infection among intubated adults in a university medical intensive care unit. Chest 1991;100:1377-84.

28. Klainer AS, Oud L, Randazzo J, Freiheiter J, Bisaccia E, Gerhard H. Herpes simplex virus involvement of the lower respiratory tract following surgery. Chest 1994;106:8S-14S.

29. Manna A, Cordani S, Canessa P, Pronzato P. CMV infection and pneumonia in hematological malignancies. J Infect Chemother 2003;9:265-7.

30. Mohsen AH, McKendrick M. Varicella pneumonia in adults. Eur Respir J 2003;21:886-91.

31. Ramsey PG, Fife KH, Hackman RC, Meyers JD, Corey L. Herpes simplex virus pneumonia: clinical, virologic, and pathologic features in 20 patients. Ann Intern Med 1982;97:813-20.

32. Retalis P, Strange C, Harley R. The spectrum of adult adenovirus pneumonia. Chest 1996;109:1656-7.

33. Stephan F, Meharzi D, Ricci S, Fajac A, Clergue F, Bernaudin JF. Evaluation by polymerase chain reaction of cytomegalovirus reactivation in intensive care patients under mechanical ventilation. Intensive Care Med 1996;22:1244-9.

34. Umans U, Golding RP, Duraku S, Manoliu RA. Herpes simplex virus 1 pneumonia: conventional chest radiograph pattern. Eur Radiol 2001;11:990-4.

35. Zahradnik JM. Adenovirus pneumonia. Semin Respir Infect 1987;2:104-11.

36. Kim EA, Lee KS, Primack SL, Yoon HK, Byun HS, Kim TS, Suh GY, Kwon OJ, Han J. Viral pneumonias in adults: radiologic and pathologic findings. Radiographics 2002;22 Spec No:S137-49.

37. Fleming DM, Zambon M. Update on influenza and other viral pneumonias. Curr Opin Infect Dis 2001;14:199-204.

38. Oikonomou A, Muller NL, Nantel S. Radiographic and high-resolution CT findings of influenza virus pneumonia in patients with hematologic malignancies. AJR Am J Roentgenol 2003;181:507-11.

39. Oliveira EC, Marik PE, Colice G. Influenza pneumonia: a descriptive study. Chest 2001;119:1717-23. 
40. Kaiser L, Wat C, Mills T, Mahoney P, Ward P, Hayden F. Impact of oseltamivir treatment on influenza-related lower respiratory tract complications and hospitalizations. Arch Intern Med 2003;163:1667-72.

41. Monto AS, Webster A, Keene O. Randomized, placebo-controlled studies of inhaled zanamivir in the treatment of influenza A and B: pooled efficacy analysis. J Antimicrob Chemother 1999;44 Suppl B:23-9.

42. Aylward RB, Burdge DR. Ribavirin therapy of adult respiratory syncytial virus pneumonitis. Arch Intern Med 1991;151:2303-4.

43. Englund JA, Piedra PA, Whimbey E. Prevention and treatment of respiratory syncytial virus and parainfluenza viruses in immunocompromised patients. Am J Med 1997;102:61-70

44. McClung HW, Knight V, Gilbert BE, Wilson SZ, Quarles JM, Divine GW. Ribavirin aerosol treatment of influenza $B$ virus infection. JAMA 1983;249:2671-4.

45. Berger A, Drosten Ch, Doerr HW, Sturmer M, Preiser W. Severe acute respiratory syndrome (SARS)--paradigm of an emerging viral infection. J Clin Virol 2004;29:13-22.

46. Manocha S, Walley KR, Russell JA. Severe acute respiratory distress syndrome (SARS): a critical care perspective. Crit Care Med 2003;31:2684-92.

47. Bitar R, Weiser WJ, Avendano M, Derkach P, Low DE, Muradali D. Chest radiographic manifestations of severe acute respiratory syndrome in health care workers: the Toronto experience. AJR Am J Roentgenol. 2004;182:45-8.

48. Chan MS, Chan IY, Fung KH, Poon E, Yam LY, Lau KY. High-resolution CT findings in patients with severe acute respiratory syndrome: a pattern-based approach. AJR Am J Roentgenol 2004;182:49-56.

49. Müller NL, Ooi GC, Khong PL, Zhou LJ, Tsang KW, Nicolaou S. Highresolution CT findings of severe acute respiratory syndrome at presentation and after admission. AJR Am J Roentgenol 2004;182:39-44.

50. Paul NS, Chung T, Konen E, Roberts HC, Rao TN, Gold WL, Mehta S, Tomlinson GA, Boylan CE, Grossman H, Hong HH, Weisbrod GL. Prognostic significance of the radiographic pattern of disease in patients with severe acute respiratory syndrome. AJR Am J Roentgenol 2004;182:493-8.

51. Glezen WP, Greenberg SB, Atmar RL, Piedra PA, Couch RB. Impact of respiratory virus infections on persons with chronic underlying conditions. JAMA 2000;283:499-505.

52. Greenberg SB, Atmar RL. "Chronic airway disease: The infection connection." In: Transactions of The American Clinical and Climatological Association 1999;Vol.CX: pp. 38-50.

53. Greenberg SB, Allen M, Wilson J, Atmar RL. Respiratory viral infections in adults with and without chronic obstructive pulmonary disease. Am J Respir Crit Care Med. 2000;162:167-73.

54. Atmar RL, Guy E, Guntupalli KK, Zimmerman JL, Bandi VD, Baxter BD, Greenberg SB. Respiratory tract viral infections in inner-city asthmatic adults. Arch Intern Med 1998;158:2453-9.

55. Tokat O, Kelebek N, Turker G, Kahveci SF, Ozcan B. Intravenous immunoglobulin in adult varicella pneumonia complicated by acute respiratory distress syndrome. J Int Med Res 2001;29:252-5.

56. Triebwasser JH, Harris RE, Bryant RE, Rhoades ER. Varicella pneumonia in adults. Report of seven cases and a review of literature. Medicine (Baltimore) 1967;46:409-23. 
57. Tuxen DV, Wilson JW, Cade JF. Prevention of lower respiratory herpes simplex virus infection with acyclovir in patients with the adult respiratory distress syndrome. Am Rev Respir Dis 1987; 136:402-5.

58. Hawes S, Seabolt JP. Hantavirus. Clin Lab Sci. 2003;16:39-42.

59. Khan A, Khan AS. Hantaviruses: a tale of two hemispheres. Panminerva Med 2003;45:43-51.

60. Lednicky JA. Hantaviruses. a short review. Arch Pathol Lab Med 2003; 127:305.

61. Howard MJ, Doyle TJ, Koster FT, Zaki SR, Khan AS, Petersen EA, Peters CJ, Bryan RT. Hantavirus pulmonary syndrome in pregnancy. Clin Infect Dis 1999;29:1538-44.

62. Moolenaar RL, Dalton C, Lipman HB, Umland ET, Gallaher M, Duchin JS, Chapman L, Zaki SR, Ksiazek TG, Rollin PE, et al. Clinical features that differentiate hantavirus pulmonary syndrome from three other acute respiratory illnesses. Clin Infect Dis 1995;21:643-9.

63. Kuwabara S. Guillain-Barre syndrome: epidemiology, pathophysiology and management. Drugs 2004;64:597-610.

64. Solomon T, Willison H. Infectious causes of acute flaccid paralysis. Curr Opin Infect Dis 2003;16:375-81.

65. Jacobs BC, Rothbarth PH, van der Meche FG, Herbrink P, Schmitz PI, de Klerk MA, van Doom PA. The spectrum of antecedent infections in Guillain-Barre syndrome: a case-control study. Neurology. 1998;51:1110-5.

66. Ray G, Ghosh B, Bhattacharyya R. Acute hepatitis B presenting as GuillainBarre syndrome. Indian J Gastroenterol 2003;22:228.

67. Steininger C, Popow-Kraupp T, Seiser A, Gueler N, Stanek G, Puchhammer E. Presence of cytomegalovirus in cerebrospinal fluid of patients with GuillainBarre syndrome. J Infect Dis 2004; 189:984-9.

68. Chroni E, Thomopoulos C, Papapetropoulos S, Paschalis C, Karatza CL. A case of relapsing Guillain-Barre syndrome associated with exacerbation of chronic hepatitis B virus hepatitis. J Neurovirol 2003;9:408-10.

69. Laurenti L, Garzia M, Sabatelli M, Piccioni P, Sora' F, Leone G. Guillain-Barre' syndrome following Varicella zoster reactivation in Chronic Lymphocytic Leukemia treated with fludarabine. Haematologica 2002;87:ECR33.

70. Pavone P, Maccarrone F, Sorge A, Piccolo G, Greco F, Caruso P, Sorge G. Guillain-Barre syndrome after varicella zoster virus infections. A case report. Minerva Pediatr 2002;54:259-62.

71. Roccatagliata L, Uccelli A, Murialdo A. Guillain-Barre syndrome after reactivation of varicella-zoster virus. N Engl J Med 2001;344:65-6.

72. Lacaille F, Zylberberg H, Hagege H, Roualdes B, Meyrignac C, Chousterman M, Girot R. Hepatitis C associated with Guillain-Barre syndrome. Liver 1998;18:49-51.

73. da Rosa-Santos OL, Moreira AM, Golfetto CA, Maceira JP, Ramos-e-Silva M. Guillain-Barre syndrome associated with varicella-zoster infection. Int J Dermatol 1996;35:603-4.

74. Ormerod IE, Cockerell OC. Guillain-Barre syndrome after herpes zoster infection: a report of 2 cases. Eur Neurol 1993;33:156-8.

75. Safranek TJ, Lawrence DN, Kurland LT, Culver DH, Wiederholt WC, Hayner NS, Osterholm MT, O'Brien P, Hughes JM. Reassessment of the association between Guillain-Barre syndrome and receipt of swine influenza vaccine in 1976-1977: results of a two-state study. Expert Neurology Group. Am J Epidemiol 1991;133:940-51. 
76. Atkins MC, Esmonde TF. Guillain-Barre syndrome associated with rubella. Postgrad Med J 1991;67:375-6.

77. Rabaud C, May T, Hoen B, Maignan M, Gerard A, Canton P. Guillain-Barre syndrome associated with hantavirus infection. Clin Infect Dis 1995;20:477-8.

78. Esack A, Teelucksingh S, Singh N. The Guillain-Barre syndrome following dengue fever. West Indian Med J 1999;48:36-7.

79. Minohara Y, Koitabashi Y, Kato T, Nakajima N, Murakami H, Masaki H, Ishiko $\mathrm{H}$. A case of Guillain-Barre syndrome associated with human parvovirus B19 infection. J Infect 1998;36:327-8.

80. Ahmed S, Libman R, Wesson K, Ahmed F, Einberg K. Guillain-Barre syndrome: An unusual presentation of West Nile virus infection. Neurology 2000;55:144-6.

81. Winer JB. Guillain Barre syndrome. Mol Pathol 2001;54:381-5.

82. Dec GW Jr, Waldman H, Southern J, Fallon JT, Hutter AM Jr, Palacios I. Viral myocarditis mimicking acute myocardial infarction. J Am Coll Cardiol 1992;20:85-9.

83. Maisch B, Ristic AD, Portig I, Pankuweit S. Human viral cardiomyopathy. Front Biosci 2003;8:s39-67.

84. Angelini A, Calzolari V, Calabrese F, Boffa GM, Maddalena F, Chioin R, Thiene G. Myocarditis mimicking acute myocardial infarction: role of endomyocardial biopsy in the differential diagnosis. Heart 2000;84:245-50.

85. Bowles NE, Richardson PJ, Olsen EG, Archard LC. Detection of Coxsackie-Bvirus-specific RNA sequences in myocardial biopsy samples from patients with myocarditis and dilated cardiomyopathy. Lancet 1986;1:1120-3.

86. Bultmann BD, Klingel K, Sotlar K, Bock CT, Baba HA, Sauter M, Kandolf R. Fatal parvovirus B19-associated myocarditis clinically mimicking ischemic heart disease: an endothelial cell-mediated disease. Hum Pathol 2003;34:92-5.

87. Galrinho A, Tavares J, Caria R, Veiga C. Myocarditis due to influenza virus complicated by intravascular coagulopathy. Rev Port Cardiol 2000;19:835-8.

88. Greaves K, Oxford JS, Price CP, Clarke GH, Crake T. The prevalence of myocarditis and skeletal muscle injury during acute viral infection in adults: measurement of cardiac troponins I and $\mathrm{T}$ in 152 patients with acute influenza infection. Arch Intern Med 2003;163:165-8.

89. Kuhl U, Pauschinger M, Bock T, Klingel K, Schwimmbeck CP, Seeberg B, Krautwurm L, Poller W, Schultheiss HP, Kandolf R. Parvovirus B19 infection mimicking acute myocardial infarction. Circulation 2003;108:945-50.

90. McGregor D, Henderson S. Myocarditis, rhabdomyolysis and myoglobinuric renal failure complicating influenza in a young adult. N Z Med J 1997;110:237.

91. Onitsuka H, Imamura T, Miyamoto N, Shibata $Y$, Kashiwagi $T$, Ayabe T, Kawagoe J, Matsuda J, Ishikawa T, Unoki T, Takenaga M, Fukunaga T, Nakagawa S, Koiwaya Y, Eto T.Clinical manifestations of influenza a myocarditis during the influenza epidemic of winter 1998-1999. J Cardiol 2001;37:315-23.

92. Orth T, Herr W, Spahn T, Voigtlander T, Michel D, Mertens T, Mayet WJ, Dippold W, Meyer zum Buschenfelde KH. Human parvovirus B19 infection associated with severe acute perimyocarditis in a 34-year-old man. Eur Heart J 1997; 18:524-5.

93. Castleberry JS, Mahon CR. Dengue fever in the Western Hemisphere. Clin Lab Sci 2003;16:34-8.

94. Guzman MG, Kouri G.Dengue and dengue hemorrhagic fever in the Americas: lessons and challenges. J Clin Virol 2003;27:1-13.

95. Halstead SB. Dengue. Curr Opin Infect Dis 2002;15:471-6. 
96. Gear JS, Cassel GA, Gear AJ, Trappler B, Clausen L, Meyers AM, Kew MC, Bothwell TH, Sher R, Miller GB, Schneider J, Koornhof HJ, Gomperts ED, Isaacson M, Gear JH. Outbreak of Marburg virus disease in Johannesburg. $\mathrm{Br}$ Med J 1975;4:489-93.

97. Heymann DL, Barakamfitiye D, Szczeniowski M, Muyembe-Tamfum JJ, Bele O, Rodier G. Ebola hemorrhagic fever: lessons from Kikwit, Democratic Republic of the Congo. J Infect Dis 1999;179 Suppl 1:S283-6.

98. Richards GA, Murphy S, Jobson R, Mer M, Zinman C, Taylor R, Swanepoel R, Duse A, Sharp G, De La Rey IC, Kassianides C.Unexpected Ebola virus in a tertiary setting: clinical and epidemiologic aspects. Crit Care Med 2000;28:2404.

99. Srichaikul T, Nimmannitya S. Haematology in dengue and dengue haemorrhagic fever. Baillieres Best Pract Res Clin Haematol 2000; 13:261-76.

100. Edelen JS, Bender TR, Chin TD.Encephalopathy and pericarditis during an outbreak of influenza. Am J Epidemiol 1974;100:79-84.

101. Kennedy PG. Viral encephalitis: causes, differential diagnosis, and management. J Neurol Neurosurg Psychiatry 2004;75 Suppl 1:i10-5.

102. McCarthy M. Newer viral encephalitides. Neurologist 2003;9:189-99.

103. Studahl M. Influenza virus and CNS manifestations. J Clin Virol. 2003;28:22532.

104. Johnson RT. Emerging viral infections of the nervous system. J Neurovirol 2003;9:140-7.

105. Whitley RJ, Cobbs CO, Alford CA Jr, Soong SJ, Hirsch MS, Connor JD, Corey L, Hanley DF, Levin M, Powell DA. Diseases that mimic herpes simplex encephalitis. Diagnosis, presentation, and outcome. NIAD Collaborative Antiviral Study Group. JAMA 1989;262:234-9.

106. Campbell GL, Marfin AA, Lanciotti RS, Gubler DJ. West Nile virus. Lancet Infect Dis 2002;2:519-29.

107. Cushing MM, Brat DJ, Mosunjac MI, Hennigar RA, Jernigan DB, Lanciotti R, Petersen LR, Goldsmith C, Rollin PE, Shieh WJ, Guarner J, Zaki SR. Fatal West Nile virus encephalitis in a renal transplant recipient. Am J Clin Pathol 2004;121:26-31.

108. Centers for Disease Control and Prevention (CDC). First human death associated with raccoon rabies--Virginia, 2003. MMWR Morb Mortal Wkly Rep 2003;52:1102-3.

109. Centers for Disease Control and Prevention (CDC). Human death associated with bat rabies--California, 2003. MMWR Morb Mortal Wkly Rep 2004;53:335 .

110. Lakeman FD, Koga J, Whitley RJ. Detection of antigen to herpes simplex virus in cerebrospinal fluid from patients with herpes simplex encephalitis. J Infect Dis 1987; 155:1172-8.

111. Emig M, Apple DJ. Severe West Nile virus disease in healthy adults. Clin Infect Dis 2004;38:289-92.

112. Petersen LR, Marfin AA. West Nile virus: a primer for the clinician. Ann Intern Med 2002;137:173-9.

113. Roehrig JT, Layton M, Smith P, Campbell GL, Nasci R, Lanciotti RS. The emergence of West Nile virus in North America: ecology, epidemiology, and surveillance. Curr Top Microbiol Immunol 2002;267:223-40.

114. Sampathkumar P. West Nile virus: epidemiology, clinical presentation, diagnosis, and prevention. Mayo Clin Proc 2003;78:1137-43.

115. Jeha LE, Sila CA, Lederman RJ, Prayson RA, Isada CM, Gordon SM. West Nile virus infection: a new acute paralytic illness. Neurology 2003;61:55-9. 
116. Kelley TW, Prayson RA, Ruiz AI, Isada CM, Gordon SM. The neuropathology of West Nile virus meningoencephalitis. A report of two cases and review of the literature. Am J Clin Pathol 2003;119:749-53.

117. Solomon T, Willison H. Infectious causes of acute flaccid paralysis. Curr Opin Infect Dis 2003;16:375-81.

118. Jemsek J, Greenberg SB, Taber L, Harvey D, Gershon A, Couch RB. Herpes zoster-associated encephalitis: clinicopathologic report of 12 cases and review of the literature. Medicine (Baltimore) 1983;62:81-97.

119. Nakano A, Yamasaki R, Miyazaki S, Horiuchi N, Kunishige M, Mitsui T. Beneficial effect of steroid pulse therapy on acute viral encephalitis. Eur Neurol 2003;50:225-9.

120. Fagan EA, Williams R. Fulminant viral hepatitis. Br Med Bull 1990;46:462-80.

121. Rezende G, Roque-Afonso AM, Samuel D, Gigou M, Nicand E, Ferre V, Dussaix E, Bismuth H, Feray C. Viral and clinical factors associated with the fulminant course of hepatitis A infection. Hepatology 2003;38:613-8.

122. Tillmann HL, Wedemeyer H, Manns MP. Treatment of hepatitis B in special patient groups: hemodialysis, heart and renal transplant, fulminant hepatitis, hepatitis B virus reactivation. J Hepatol 2003;39:S206-11.

123. Schiodt FV, Davern TJ, Shakil AO, McGuire B, Samuel G, Lee WM.Viral hepatitis-related acute liver failure. Am J Gastroenterol. 2003;98:448-53.

124. Anderson DR, Schwartz J, Hunter NJ, Cottrill C, Bisaccia E, Klainer AS. Varicella hepatitis: a fatal case in a previously healthy, immunocompetent adult. Report of a case, autopsy, and review of the literature. Arch Intern Med 1994;154:2101-6.

125. Anuras S, Summers R. Fulminant herpes simplex hepatitis in an adult: report of a case in renal transplant recipient. Gastroenterology 1976;70:425-8.

126. Kusne S, Schwartz M, Breinig MK, Dummer JS, Lee RE, Selby R, Starzl TE, Simmons RL, Ho M. Herpes simplex virus hepatitis after solid organ transplantation in adults. J Infect Dis 1991;163:1001-7.

127. Harma M, Hockerstedt K, Lautenschlager I.Human herpesvirus-6 and acute liver failure.Transplantation. 2003;76:536-9.

128. Pesik NT, Otten EJ. Severe rhabdomyolysis following a viral illness: a case report and review of the literature. J Emerg Med 1996;14:425-8.

129. Singh U, Scheld WM. Infectious etiologies of rhabdomyolysis: three case reports and review. Clin Infect Dis 1996;22:642-9.

130. Leebeek FW, Baggen MG, Mulder LJ, Dingemans-Dumas AM. Rhabdomyolysis associated with influenza A virus infection. Neth $\mathrm{J}$ Med 1995;46:189-92.

131. Seibold S, Merkel F, Weber M, Marx M. Rhabdomyolysis and acute renal failure in an adult with measles virus infection. Nephrol Dial Transplant 1998;13:182931.

132. Annerstedt M, Herlitz H, Molne J, Oldfors A, Westberg G. Rhabdomyolysis and acute renal failure associated with influenza virus type A. Scand J Urol Nephrol 1999;33:260-4.

133. Berry L, Braude S. Influenza A infection with rhabdomyolysis and acute renal failure--a potentially fatal complication. Postgrad Med J 1991;67:389-90.

134. Cunningham E, Kohli R, Venuto RC. Influenza-associated myoglobinuric renal failure. JAMA 1979;242:2428-9.

135. Fodili F, van Bommel EF. Severe rhabdomyolysis and acute renal failure following recent Coxsackie B virus infection. Neth J Med 2003;61:177-9. 
136. Hollenstein U, Thalhammer F, Burgmann H. Disseminated intravascular coagulation (DIC) and rhabdomyolysis in fulminant varicella infection--case report and review of the literature. Infection 1998;26:306-8.

137. Josselson J, Pula T, Sadler JH. Acute rhabdomyolysis associated with an echovirus 9 infection. Arch Intern Med 1980;140:1671-2.

138. Kantor RJ, Norden CW, Wein TP. Infectious mononucleosis associated with rhabdomyolysis and renal failure. South Med J 1978;71:346-8.

139. Marinella MA. Exertional rhabdomyolysis after recent coxsackie B virus infection. South Med J 1998;91:1057-9.

140. McCabe JL, Duckett S, Kaplan P. Epstein-Barr virus infection complicated by acute rhabdomyolysis. Am J Emerg Med 1988;6:453-5.

141. Morton SE, Mathai M, Byrd RP Jr, Fields CL, Roy TM. Influenza A pneumonia with rhabdomyolysis. South Med J 2001;94:67-9.

142. Nozoe M, Iino T, Nagafuji K, Miyamoto T, Ito H, Gondo H, Harada M. Influenza-induced rhabdomyolysis after autologous peripheral blood stem cell transplantation for malignant lymphoma. Intern Med 2003;42:1127-30.

143. Osamah H, Finkelstein R, Brook JG. Rhabdomyolysis complicating acute Epstein-Barr virus infection. Infection 1995;23:119-20.

144. Pratt RD, Bradley JS, Loubert C, LaRocco A Jr, McNeal RM, Newbury RO, Sawyer MH. Rhabdomyolysis associated with acute varicella infection. Clin Infect Dis 1995;20:450-3.

145. Shenouda A, Hatch FE. Influenza A viral infection associated with acute renal failure. Am J Med 1976;61:697-702.

146. Tanaka T, Takada T, Takagi D, Takeyama N, Kitazawa Y. Acute renal failure due to rhabdomyolysis associated with echovirus 9 infection: a case report and review of literature. Jpn J Med 1989;28:237-42.

147. Ueda K, Robbins DA, Iitaka K, Linnemann CC Jr. Fatal rhabdomyolysis associated with parainfluenza type 3 infection. Hiroshima J Med Sci 1978;27:99103.

148. Wakabayashi Y, Nakano T, Kikuno T, Ohwada T, Kikawada R. Massive rhabdomyolysis associated with influenza A infection. Intern Med 1994;33:4503.

149. Wright J, Couchonnal G, Hodges GR. Adenovirus type 21 infection. Occurrence with pneumonia, rhabdomyolysis, and myoglobinuria in an adult. JAMA 1979;241:2420-1.

150. Yamada H, Ono T, Kimura M. Rhabdomyolysis in adults with measles virus infection. Am J Med 2000;108:600.

151. Yoshino M, Suzuki S, Adachi K, Fukayama M, Inamatsu T. High incidence of acute myositis with type A influenza virus infection in the elderly. Intern Med 2000;39:431-2.

152. Alvares-Da-Silva MR, Francisconi CF, Waechter FL. Acute hepatitis C complicated by pancreatitis: another extrahepatic manifestation of hepatitis C virus? J Viral Hepat 2000;7:84-6.

153. Cavallari A, Vivarelli M, D'Errico A, Bellusci R, Scarani P, DeRaffele E, Nardo B, Gozzetti G. Fatal necrotizing pancreatitis caused by hepatitis B virus infection in a liver transplant recipient. J Hepatol 1995;22:685-90.

154. de Oliveira LC, Rezende PB, Ferreira AL, de Freitas AA, de Carvalho AM, Guedes CA, Costa WO. Concurrent acute hepatitis and pancreatitis associated with hepatitis B virus: case report. Pancreas 1998;16:559-61.

155. Ikura Y, Matsuo T, Ogami M, Yamazaki S, Okamura M, Yoshikawa J, Ueda M. Cytomegalovirus associated pancreatitis in a patient with systemic lupus erythematosus. J Rheumatol 2000;27:2715-7. 
156. Khanna S, Vij JC. Severe acute pancreatitis due to hepatitis A virus infection in a patient of acute viral hepatitis. Trop Gastroenterol 2003;24:25-6.

157. Majumder AK, Halder A, Talapatra DS, Bhaduri S. Hepatitis E associated with acute pancreatitis with pseudocyst. J Assoc Physicians India 1999;47:1207-8.

158. Shintaku M, Umehara Y, Iwaisako K, Tahara M, Adachi Y. Herpes simplex pancreatitis. Arch Pathol Lab Med 2003;127:231-4.

159. Suskovic T, Vukicevic-Baudoin D, Vucicevic Z, Holjevac I. Severe pancreatitis as first symptom of mumps complicated with pseudocyst and abscess of pancreas. Infection 1997;25:39-40.

160. Yuen MF, Chan TM, Hui CK, Chan AO, Ng IO, Lai CL. Acute pancreatitis complicating acute exacerbation of chronic hepatitis $\mathrm{B}$ infection carries a poor prognosis. J Viral Hepat 2001;8:459-64.

161. Crupi RS, Asnis DS, Lee CC, Santucci T, Marino MJ, Flanz BJ. Meeting the challenge of bioterrorism: lessons learned from West Nile virus and anthrax. Am J Emerg Med 2003;21:77-9.

162. Karwa M, Bronzert P, Kvetan V. Bioterrorism and critical care. Crit Care Clin 2003;19:279-313.

163. Han MH, Zunt JR. Bioterrorism and the nervous system. Curr Neurol Neurosci Rep 2003;3:476-82.

164. Henderson DA, Inglesby TV, Bartlett JG, Ascher MS, Eitzen E, Jahrling PB, Hauer J, Layton M, McDade J, Osterholm MT, O’Toole T, Parker G, Perl T, Russell PK, Tonat K. Smallpox as a biological weapon: medical and public health management. Working Group on Civilian Biodefense. JAMA 1999;281:2127-37.

165. Pennington H. Smallpox and bioterrorism. Bull World Health Organ 2003;81:762-7.

166. Breman JG, Henderson DA. Diagnosis and management of smallpox. N Engl J Med 2002;346:1300-8.

167. Nuovo GJ, Plaza JA, Magro C. Rapid diagnosis of smallpox infection and differentiation from its mimics. Diagn Mol Pathol 2003;12:103-7.

168. Baker RO, Bray M, Huggins JW. Potential antiviral therapeutics for smallpox, monkeypox and other orthopoxvirus infections. Antiviral Res 2003;57:13-23.

169. Safrin S, Cherrington J, Jaffe HS. Cidofovir. Review of current and potential clinical uses. Adv Exp Med Biol 1999;458:111-20.

170. Frey SE, Couch RB, Tacket CO, Treanor JJ, Wolff M, Newman FK, Atmar RL, Edelman R, Nolan CM, Belshe RB; National Institute of Allergy and Infectious Diseases Smallpox Vaccine Study Group. Clinical responses to undiluted and diluted smallpox vaccine. N Engl J Med 2002;346:1265-74.

171. Bausch DG, Ksiazek TG. Viral hemorrhagic fevers including hantavirus pulmonary syndrome in the Americas. Clin Lab Med 2002;22:981-1020.

172. Bourdarias B, Perro G, Cutillas M, Castede JC, Lafon ME, Sanchez R. Herpes simplex virus infection in burned patients: epidemiology of 11 cases. Burns 1996;22:287-90.

173. Byers RJ, Hasleton PS, Quigley A, Dennett C, Klapper PE, Cleator GM, Faragher EB. Pulmonary herpes simplex in burns patients. Eur Respir J 1996;9:2313-7.

174. Foley FD, Greenawald KA, Nash G, Pruitt BA Jr. Herpesvirus infection in burned patients. N Engl J Med 1970;282:652-6.

175. Brandt SJ, Tribble CG, Lakeman AD, Hayden FG. Herpes simplex burn wound infections: epidemiology of a case cluster and responses to acyclovir therapy. Surgery $1985 ; 98: 338-43$. 
176. Cherr GS, Meredith JW, Chang M. Herpes simplex virus pneumonia in trauma patients. J Trauma 2000;49:547-9.

177. Fidler PE, Mackool BT, Schoenfeld DA, Malloy M, Schulz JT 3rd, Sheridan RL, Ryan CM. Incidence, outcome, and long-term consequences of herpes simplex virus type 1 reactivation presenting as a facial rash in intubated adult burn patients treated with acyclovir. J Trauma. 2002;53:86-9.

178. Sheridan RL, Schulz JT, Weber JM, Ryan CM, Pasternack MS, Tompkins RG. Cutaneous herpetic infections complicating burns. Burns 2000;26:621-4.

179. Sherry MK, Klainer AS, Wolff M, Gerhard H. Herpetic tracheobronchitis. Ann Intern Med 1988;109:229-33.

180. Jacobs F, Knoop C, Brancart F, Gilot P, Melot C, Byl B, Delforge ML, Estenne M, Liesnard C; Brussels Heart and Lung Transplantation Group. Human herpesvirus-6 infection after lung and heart-lung transplantation: a prospective longitudinal study. Transplantation. 2003;75:1996-2001.

181. Prellner T, Flamholc L, Haidl S, Lindholm K, Widell A. Herpes simplex virus-the most frequently isolated pathogen in the lungs of patients with severe respiratory distress. Scand J Infect Dis 1992;24:283-92.

182. Ong GM, Lowry K, Mahajan S, Wyatt DE, Simpson C, O’Neill HJ, McCaughey C, Coyle PV. Herpes simplex type 1 shedding is associated with reduced hospital survival in patients receiving assisted ventilation in a tertiary referral intensive care unit. J Med Virol 2004;72:121-5.

183. Bruynseels P, Jorens PG, Demey HE, Goossens H, Pattyn SR, Elseviers MM, Weyler J, Bossaert LL, Mentens Y, Ieven M. Herpes simplex virus in the respiratory tract of critical care patients: a prospective study. Lancet 2003;362:1536-41.

184. Camps K, Jorens PG, Demey HE, Pattyn SR, Ieven M. Clinical significance of herpes simplex virus in the lower respiratory tract of critically ill patients. Eur J Clin Microbiol Infect Dis 2002;21:758-9.

185. Schuller D. Lower respiratory tract reactivation of herpes simplex virus. Comparison of immunocompromised and irnmunocompetent hosts. Chest. 1994;106:3S-7S.

186. Cook CH, Martin LC, Yenchar JK, Lahm MC, McGuinness B, Davies EA, Ferguson RM. Occult herpes family viral infections are endemic in critically ill surgical patients. Crit Care Med 2003;31:1923-9.

187. Cook CH, Yenchar JK, Kraner TO, Davies EA, Ferguson RM. Occult herpes family viruses may increase mortality in critically ill surgical patients. Am J Surg 1998;176:357-60.

188. Konoplev S, Champlin RE, Giralt S, Ueno NT, Khouri I, Raad I, Rolston K, Jacobson K, Tarrand J, Luna M, Nguyen Q, Whimbey E. Cytomegalovirus pneumonia in adult autologous blood and marrow transplant recipients. Bone Marrow Transplant 2001;27:877-81.

189. Ie S, Rubio ER, Alper B, Szerlip HM. Respiratory complications of pregnancy. Obstet Gynecol Surv. 2002;57:39-46.

190. Lim WS, Macfarlane JT, Colthorpe CL. Treatment of community-acquired lower respiratory tract infections during pregnancy. Am J Respir Med 2003;2:221-33.

191. Atmar RL, Englund JA, Hammill H. Complications of measles during pregnancy. Clin Infect Dis 1992;14:217-26.

192. Maupin RT. Obstetric infectious disease emergencies. Clin Obstet Gynecol. 2002;45:393-404.

193. McKinney WP, Volkert P, Kaufman J. Fatal swine influenza pneumonia during late pregnancy. Arch Intern Med. 1990;150:213-5. 
194. Rodrigues J, Niederman MS. Pneumonia complicating pregnancy. Clin Chest Med. 1992;13:679-91.

195. McCarter-Spaulding DE. Varicella infection in pregnancy. J Obstet Gynecol Neonatal Nurs. 2001;30:667-73.

196. Broussard RC, Payne DK, George RB. Treatment with acyclovir of varicella pneumonia in pregnancy. Chest 1991;99:1045-7.

197. Money DM. Antiviral and antiretroviral use in pregnancy. Obstet Gynecol Clin North Am 2003;30:731-49

198. Smego RA Jr, Asperilla MO. Use of acyclovir for varicella pneumonia during pregnancy. Obstet Gynecol 1991;78:1112-6.

199. Chapman SJ. Varicella in pregnancy. Semin Perinatol. 1998;22:339-46.

200. Desselberger U. Herpes simplex virus infection in pregnancy: diagnosis and significance. Intervirology 1998;41:185-90.

201. Frederick DM, Bland D, Gollin Y. Fatal disseminated herpes simplex virus infection in a previously healthy pregnant woman. A case report. J Reprod Med 2002;47:591-6.

202. Kang AH, Graves CR. Herpes simplex hepatitis in pregnancy: a case report and review of the literature. Obstet Gynecol Surv 1999;54:463-8.

203. Baker DA. Issues and management of herpes in pregnancy. Int J Fertil Womens Med. 2002;47:129-35.

204. Godet C, Beby-Defaux A, Agius G, Pourrat O, Robert R.Maternal Herpes simplex virus type 2 encephalitis following Cesarean section. J Infect. 2003;47:174-5.

205. Suarez VR, Hankins GD. Smallpox and pregnancy: from eradicated disease to bioterrorist threat. Obstet Gynecol. 2002;100:87-93.

206. Kojaoghlanian T, Flomenberg P, Horwitz MS. The impact of adenovirus infection on the immunocompromised host. Rev Med Virol. 2003;13:155-71.

207. Meijer E, Boland GJ, Verdonck LF. Prevention of cytomegalovirus disease in recipients of allogeneic stem cell transplants. Clin Microbiol Rev. 2003;16:64757.

208. Middeldorp JM. Molecular diagnosis of viral infections in renal transplant recipients. Curr Opin Nephrol Hypertens. 2002;11:665-72.

209. Wang WH, Wang HL. Fulminant adenovirus hepatitis following bone marrow transplantation. A case report and brief review of the literature. Arch Pathol Lab Med 2003;127:e246-8.

210. Waser M, Maggiorini M, Luthy A, Laske A, von Segesser L, Mohacsi P, Opravil M, Turina M, Follath F, Gallino A.Infectious complications in 100 consecutive heart transplant recipients. Eur J Clin Microbiol Infect Dis. 1994;13:12-8.

211. Wiesner RH, Rakela J, Ishitani MB, Mulligan DC, Spivey JR, Steers JL, Krom RA. Recent advances in liver transplantation. Mayo Clin Proc. 2003;78:197-210.

212. Nicholson V, Johnson PC.Infectious complications in solid organ transplant recipients. Surg Clin North Am. 1994;74:1223-45.

213. Rubin RH. The direct and indirect effects of infection in liver transplantation: pathogenesis, impact, and clinical management. Curr Clin Top Infect Dis 2002;22:125-54.

214. Alexander BD, Tapson VF. Infectious complications of lung transplantation. Transpl Infect Dis 2001;3:128-37.

215. Cavallo R, Merlino C, Re D, Bollero C, Bergallo M, Lembo D, Musso T, Leonardi G, Segoloni GP, Ponzi AN. B19 virus infection in renal transplant recipients. J Clin Virol 2003;26:361-8. 
216. Wendt $\mathrm{CH}$, Hertz MI. Respiratory syncytial virus and parainfluenza virus infections in the immunocompromised host. Semin Respir Infect 1995;10:22431.

217. Wendt CH, Weisdorf DJ, Jordan MC, Balfour HH Jr, Hertz MI. Parainfluenza virus respiratory infection after bone marrow transplantation. $\mathrm{N}$ Engl $\mathrm{J}$ Med 1992;326:921-6.

218. Whimbey E, Elting LS, Couch RB, Lo W, Williams L, Champlin RE, Bodey GP. Influenza A virus infections among hospitalized adult bone marrow transplant recipients. Bone Marrow Transplant 1994;13:437-40.

219. Win N, Mitchell D, Pugh S, Russell NH. Successful therapy with ribavirin of late onset respiratory syncytial virus pneumonitis complicating allogeneic bone transplantation. Clin Lab Haematol 1992; 14:29-32.

220. Harrington RD, Hooton TM, Hackman RC, Storch GA, Osborne B, Gleaves CA, Benson A, Meyers JD. An outbreak of respiratory syncytial virus in a bone marrow transplant center. J Infect Dis 1992;165:987-93.

221. Lewis VA, Champlin R, Englund J, Couch R, Goodrich JM, Rolston K, Przepiorka D, Mirza NQ, Yousuf HM, Luna M, Bodey GP, Whimbey E. Respiratory disease due to parainfluenza virus in adult bone marrow transplant recipients. Clin Infect Dis 1996;23:1033-7.

222. Morales R, Kirkpatrick M, Browne B, Emovon O. Respiratory syncytial virus pneumonia in an adult renal transplant patient: an unexpected nosocomial infection. Infect Control Hosp Epidemiol 2003;24:548-50.

223. Ohori NP, Michaels MG, Jaffe R, Williams P, Yousem SA. Adenovirus pneumonia in lung transplant recipients. Hum Pathol 1995;26:1073-9.

224. Peigue-Lafeuille H, Gazuy N, Mignot P, Deteix P, Beytout D, Baguet JC. Severe respiratory syncytial virus pneumonia in an adult renal transplant recipient: successful treatment with ribavirin. Scand J Infect Dis 1990;22:87-9.

225. Nichols WG, Corey L, Gooley T, Davis C, Boeckh M. Parainfluenza virus infections after hematopoietic stem cell transplantation: risk factors, response to antiviral therapy, and effect on transplant outcome. Blood 2001;98:573-8.

226. Nichols WG, Gooley T, Boeckh M.Community-acquired respiratory syncytial virus and parainfluenza virus infections after hematopoietic stem cell transplantation: the Fred Hutchinson Cancer Research Center experience. Biol Blood Marrow Transplant. 2001;7 Suppl:11S-15S.

227. Small TN, Casson A, Malak SF, Boulad F, Kiehn TE, Stiles J, Ushay HM, Sepkowitz KA. Respiratory syncytial virus infection following hematopoietic stem cell transplantation. Bone Marrow Transplant 2002;29:321-7.

228. Cane PA, van den Hoogen BG, Chakrabarti S, Fegan CD, Osterhaus AD. Human metapneumovirus in a haematopoietic stem cell transplant recipient with fatal lower respiratory tract disease. Bone Marrow Transplant 2003;31:309-10.

229. Kahn JS. Human metapneumovirus: a newly emerging respiratory pathogen. Curr Opin Infect Dis 2003;16:255-8.

230. Ghosh S, Champlin RE, Englund J, Giralt SA, Rolston K, Raad I, Jacobson K, Neumann J, Ippoliti C, Mallik S, Whimbey E. Respiratory syncytial virus upper respiratory tract illnesses in adult blood and marrow transplant recipients: combination therapy with aerosolized ribavirin and intravenous immunoglobulin. Bone Marrow Transplant 2000;25:751-5.

231. Ljungman P, Gleaves CA, Meyers JD. Respiratory virus infection in immunocompromised patients. Bone Marrow Transplant 1989;4:35-40.

232. Ison MG, Hayden FG. Viral infections in immunocompromised patients: what's new with respiratory viruses? Curr Opin Infect Dis. 2002;15:355-67. 
233. Garbino J, Gerbase MW, Wunderli W, Kolarova L, Nicod LP, Rochat T, Kaiser L. Respiratory viruses and severe lower respiratory tract complications in hospitalized patients. Chest. 2004;125:1033-9.

234. Vilchez RA, Dauber J, McCurry K, Iacono A, Kusne S.Parainfluenza virus infection in adult lung transplant recipients: an emergent clinical syndrome with implications on allograft function. Am J Transplant. 2003;3:116-20.

235. Gray J, Wreghitt TG, Pavel P, Smyth RL, Parameshwar J, Stewart S, Cary N, Large S, Wallwork J. Epstein-Barr virus infection in heart and heart-lung transplant recipients: incidence and clinical impact. J Heart Lung Transplant 1995;14:640-6.

236. Parnham AP, Flexman JP, Saker BM, Thatcher GN. Primary varicella in adult renal transplant recipients: a report of three cases plus a review of the literature. Clin Transplant 1995;9:115-8.

237. Singh N. Human herpesviruses-6, -7 and -8 in organ transplant recipients. Clin Microbiol Infect 2000;6:453-9.

238. Taplitz RA, Jordan MC. Pneumonia caused by herpesviruses in recipients of hematopoietic cell transplants. Semin Respir Infect. 2002; 17:121-9.

239. Peterson PK, Balfour HH Jr, Marker SC, Fryd DS, Howard RJ, Simmons RL. Cytomegalovirus disease in renal allograft recipients: a prospective study of the clinical features, risk factors and impact on renal transplantation. Medicine (Baltimore) 1980;59:283-300.

240. Sissons JG, Carmichael AJ. Clinical aspects and management of cytomegalovirus infection. J Infect. 2002;44:78-83.

241. Ettinger NA, Bailey TC, Trulock EP, Storch GA, Anderson D, Raab S, Spitznagel EL, Dresler C, Cooper JD. Cytomegalovirus infection and pneumonitis. Impact after isolated lung transplantation. Washington University Lung Transplant Group. Am Rev Respir Dis 1993;147:1017-23.

242. de Maar EF, Verschuuren EA, Harmsen MC, The TH, van Son WJ. Pulmonary involvement during cytomegalovirus infection in immunosuppressed patients. Transpl Infect Dis 2003;5:112-20.

243. Duncan SR, Grgurich WF, Iacono AT, Burckart GJ, Yousem SA, Paradis IL, Williams PA, Johnson BA, Griffith BP. A comparison of ganciclovir and acyclovir to prevent cytomegalovirus after lung transplantation. Am J Respir Crit Care Med 1994;150:146-52.

244. Fishman JA, Doran MT, Volpicelli SA, Cosimi AB, Flood JG, Rubin RH. Dosing of intravenous ganciclovir for the prophylaxis and treatment of cytomegalovirus infection in solid organ transplant recipients. Transplantation 2000;69:389-94.

245. Zamora MR. Controversies in lung transplantation: management of cytomegalovirus infections. J Heart Lung Transplant. 2002;21:841-9.

246. Emanuel D, Cunningham I, Jules-Elysee K, Brochstein JA, Kernan NA, Laver J, Stover D, White DA, Fels A, Polsky B, et al. Cytomegalovirus pneumonia after bone marrow transplantation successfully treated with the combination of ganciclovir and high-dose intravenous immune globulin. Ann Intern Med 1988; 109:777-82.

247. Limaye AP. Antiviral resistance in cytomegalovirus: an emerging problem in organ transplant recipients. Semin Respir Infect. 2002;17:265-73.

248. Ramsey PS, Ramin KD. Pneumonia in pregnancy. Obstet Gynecol Clin North Am 2001;28:553-69.

249. Hebart H, Einsele H. Specific infectious complications after stem cell transplantation. Support Care Cancer. 2004 Feb;12(2):80-5. 
250. Jenkins FJ, Rowe DT, Rinaldo CR Jr. Herpesvirus infections in organ transplant recipients. Clin Diagn Lab Immunol. 2003;10:1-7.

251. Reusser P. Challenges and options in the management of viral infections after stem cell transplantation. Support Care Cancer. 2002;10:197-203.

252. Hong DS, Jacobson KL, Raad II, de Lima M, Anderlini P, Fuller GN, Ippoliti C, Cool RM, Leeds NE, Narvios A, Han XY, Padula A, Champlin RE, Hosing C. West Nile encephalitis in 2 hematopoietic stem cell transplant recipients: case series and literature review. Clin Infect Dis 2003;37:1044-9.

253. Gouarin S, Vabret A, Gault E, Petitjean J, Regeasse A, de Ligny BH, Freymuth F. Quantitative analysis of HCMV DNA load in whole blood of renal transplant patients using real-time PCR assay. J Clin Virol 2004;29:194-201. 